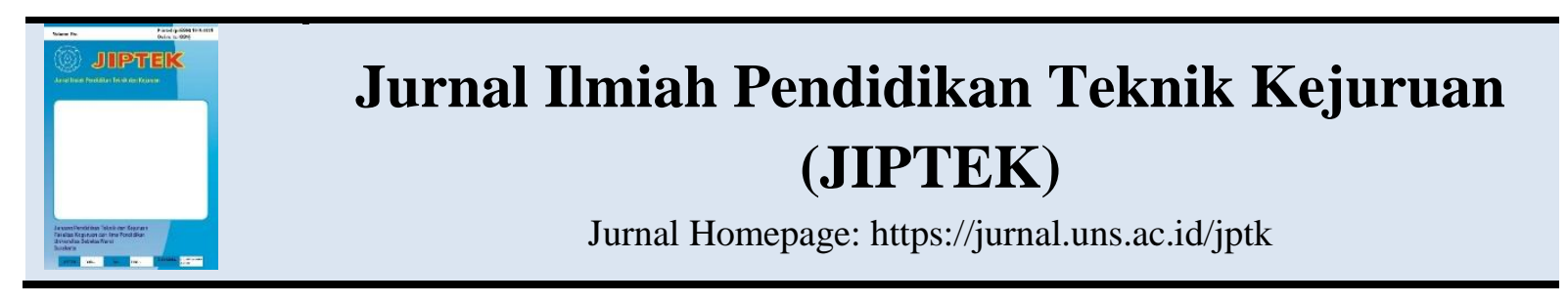

\title{
EVALUASI PELAKSANAAN PRAKTIK INDUSTRI DENGAN MENGGUNAKAN MODEL CIPP PADA PROGRAM STUDI PENDIDIKAN TEKNIK MESIN UNIVERSITAS SEBELAS MARET SURAKARTA
}

\author{
Joko Riyanto, Muhammad Akhyar, Budi Harjanto \\ Program Studi Pendidikan Teknik Bangunan, FKIP, Universitas Sebelas Maret Surakarta \\ Jalan Ahmad Yani 200 Surakarta \\ Email: sijack99@yahoo.co.id
}

\begin{abstract}
ABSTRAK
Tujuan dari penelitian ini adalah untuk mengevaluasi: (1) konteks (context) Program Praktik Industri meliputi (a) tujuan Program Praktik Industri, (b) sasaran Program Praktik Industri, (c) relevansi Program Praktik Industri, (d) sistem pengelolaan Program Praktik Industri; (2) masukan (input) Program Praktik Industri yang meliputi (a) penyiapan pengelolaan Program Praktik Industri, (b) penyiapan kompetensi mahasiswa; (3) proses (process) pelaksanaan Program Praktik Industri yang meliputi (a) peran mahasiswa (b) peran dosen pembimbing (c) peran instruktur industri (d) hambatan pelaksanaan Program Praktik Industri; (4) produk (product) Program Praktik Industri meliputi (a) pengembangan personalitas mahasiswa (b) pengembangan keterampilan mahasiswa (c) kesiapan kerja mahasiswa (d) pengalaman inovatif mahasiswa (e) kepuasan mahasiswa. Penelitian ini menggunakan metode penelitian deskriptif evaluatif model CIPP (Context, Input, Process, Product).Sampel penelitian menggunakan teknik purposive sampling yaitu koordinator Program Praktik Industri, Dunia Industri (DU/DI), dan mahasiswa Program Studi Pendidikan Teknik Mesin pelaksana Program Praktik Industri periode 2015 dan periode 2016. Teknik pengumpulan data menggunakan angket, observasi, dan wawancara. Validitas yang digunakan dalam penelitian ini adalah validitas logika. Teknik analisis kuisioner yang digunakan dalam penelitian ini melalui analisis rata-rata yang dinilai berdasarkan kriteria penilaian. Hasil penelitian menunjukkan: (1) evaluasi terhadap konteks (context) Program Praktik Industri tergolong tinggi, aspek ini meliputi: (a) ketercapaian tujuan Program terhadap pelaksanaan Praktik Industri, (b) ketercapaian sasaran Program terhadap pelaksanaan Praktik Industri, (c) adanya relevansi Program Praktik Industri dengan Dunia Industri (DU/DI), (d) adanya sistem pengelolaan Program Praktik Industri yang baik; (2) evaluasi terhadap masukan (input) Program Praktik Industri tergolong cukup. Aspek masukan meliputi: (a) penyiapan pengelolaan Program Praktik Industri, (b) penyiapan kompetensi mahasiswa; (3) evaluasi terhadapproses (process) pelaksanaan Program Praktik Industri tergolong cukup. Aspek proses yang meliputi: (a) peran mahasiswa (b) peran dosen pembimbing (c) peran instruktur industri (d) hambatan pelaksanaan Program Praktik Industri; (4) evaluasi terhadap produk (product) Program Praktik Industri tergolong tinggi. Aspek produk meliputi: (a) pengembangan personalitas mahasiswa (b) pengembangan keterampilan mahasiswa (c) kesiapan kerja mahasiswa (d) pengalaman inovatif mahasiswa (e) kepuasan mahasiswa.
\end{abstract}

Kata kunci: Evaluasi Program, CIPP, Program Praktik Industri 


\section{PENDAHULUAN}

Indonesia termasuk negara yang tergabung dalam Masyarakat Ekonomi ASEAN (MEA) atau ASEAN Economic Community (AEC) yang mulai terlaksana di akhir tahun 2015. MEA adalah realisasi pasar bebas di Asia Tenggara yang sebelumnya disebut Framework Agreement on Enhancing ASEAN Economic Cooperation pada tahun 1992. Salah satu dampak dari dibukanya pasar bebas di Asia Tenggara adalah lingkup kerja untuk masyarakat Indonesia akan semakin kecil khususnya bagi tenaga pendidik di Indonesia yang secara tidak langsung harus mampu bersaing dengan tenaga pendidik dari negara tetangga. Salah satu hambatan yang dialami oleh Indonesia adalah rendahnya mutu tenaga kependidikan di Indonesia, serta penduduk yang paling tinggi mengalami tingkat pengangguran adalah kalangan sarjana atau tingkat Universitas.

Rasio meningkatnya pengangguran di Indonesia terutama meningkatnya pengangguran untuk tingkat Universitas selalu mengalami kenaikan, dijelaskan bahwa pada bulan Februari 2015 tingkat pengangguran terbuka untuk pendidikan Diploma I/II/III dan tingkat Universitas mengalami kenaikan dari 5,72 persen pada bulan Februari 2013 menjadi 5,87 persen pada bulan Februari 2014, hingga mencapai angka 7,49 persen pada bulan Februari 2015. Sedangkan untuk tingkat Universitas mengalami penurunan dengan angka 4,31 persen pada bulan Februari 2014 dari tahun sebelumnya pada angka 5,02 pada bulan Februari 2013, akan tetapi angka pengangguran tingkat Universitas mengalami kenaikan yang signifikan sebesar 5,34 persen pada bulan Februari 2015. Salah satu faktor naiknya angka pengangguran tingkat Universitas adalah tidak terserapnya lulusan oleh dunia industri, karena minimnya lapangan pekerjaan serta tidak memiliki kualifikasi maupun kompetensi yang dibutuhkan oleh pasar kerja.

Masalah utama yang terjadi pada dunia pendidikan di Indonesia saat ini adalah kualitas pendidikan yang masih rendah serta kurang relevannya antara kualitas hasil pendidikan dengan tuntutan kebutuhan tenaga kerja yang terampil dengan jumlah yang memadai untuk memenuhi kebutuhan tenaga kerja di dunia industri maupun membuka lapangan pekerjaan baru. Dengan mengamati semakin tingginya angka pengangguran lulusan perguruan tinggi, hal ini merupakan tamparan keras untuk perguruan tinggi agar nantinya lebih meningkatkan kualitas mutu pendidikan.

Dalam menjawab tantangan yang diberikan oleh dunia industri maupun 
dunia usaha demi menekan angka pengangguran khususnya bagi kalangan lulusan Universitas, Program Studi Pendidikan Teknik Mesin Fakultas Keguruan dan Ilmu Pendidikan Universitas Sebelas Maret telah menerapkan mata kuliah Program Praktik Industri pada semester 6 dengan bobot 2 SKS. Praktik Industri merupakan praktik kerja di lapangan yang dilakukan oleh mahasiswa guna menerapkan dan membuktikan teori yang telah diberikan di bangku perkuliahan dengan praktik sesungguhnya di lapangan atau dunia industri. Dengan dilaksanakannya Program Praktik Industri, mahasiswa diharapkan mampu mengaplikasikan ilmu yang telah mereka dapat di bangku perkuliahan sehingga mampu melaksanakan kegiatan praktik yang sesungguhnya di dunia industri. Dengan adanya Praktik industri, mahasiswa mendapatkan ilmu baru yang belum didapatkan dibangku perkuliahan sebelumnya. Setelah mahasiswa melaksanakan Praktik Industri, diwajibkan untuk menyusun laporan hasil praktik di dunia industri tersebut dan melakukan seminar Praktik Industri dihadapan dosen pembimbing dan teman mahasiswa.

Kegiatan Praktik Industri mampu meningkatkan dan melatih etos kerja mahasiswa yang meliputi melatih kreatifitas, disiplin waktu, kerjasama tim, kemampuan kerja, motivasi kerja, hasil kerja yang berkualitas, serta rajin dalam melakukan setiap pekerjaan sesuai dengan tujuan Program Praktik Industri Program Studi Pendidikan Teknik Mesin Universitas Sebelas Maret. Mahasiswa Program Studi Pendidikan Teknik Mesin lebih banyak dibekali kemampuan teoritis, padahal sebagian besar dari mahasiswanya berasal dari lulusan Sekolah Menengah Atas (SMA), hal inilah yang menyebabkan perbedaan antara teori yang didapatkan dibangku kuliah dengan praktik kerja di dunia industri nantinya.

\section{METODE PENELITIAN}

Penelitian ini dilaksanakan di Kampus V Universitas Sebelas Maret Surakarta Fakultas Keguruan dan Ilmu Pendidikan Program Studi Pendidikan Teknik Mesin yang beralamat di jalan Ahmad Yani 200 Kartasura, Surakarta, sebagai institusi pelaksana dan sumber informasi pelaksanaan program Praktik Industri serta 9 perusahaan di wilayah karesidenan Surakarta. Tujuan dari penelitian ini adalah untuk mengevaluasi program Praktik Industri yang ada di Program Studi Pendidikan Teknik Mesin Universitas Sebelas Maret Surakarta.

Penelitian ini dilaksanakan secara bertahap dimulai pada bulan Januari 2016 hingga bulan April 2016. Penelitian ini menggunakan model evaluasi CIPP. Model evaluasi ini digunakan untuk mengukur pencapaian pelaksanaan Praktik Industri pada Program Studi Pendidikan 
Teknik Mesin Fakultas Keguruan dan Ilmu Pendidikan UNS pada tahun 2015 dan 2016 ditinjau dari aspek evaluasi konteks (context evaluation), evaluasi masukan (input evaluation), evaluasi proses (process evaluation), dan evaluasi produk (product evaluation).

Objek dalam penelitian ini adalah pelaksanaan program Praktik Industri yang dilaksanakan di Program Studi Pendidikan Teknik Mesin Fakultas Keguruan dan Ilmu Pendidikan Universitas Sebelas Maret Surakarta. Sumber data/responden dalam penelitian ini adalah koordinator Praktik Industri, instruktur industri, dan mahasiswa di Program Studi Pendidikan Teknik Mesin. Mahasiswa yang dijadikan responden adalah mahasiswa yang telah melaksanakan Praktik Industri pada tahun 2015 dan 2016. Teknik pengambilan sampel purposive sampling digunakan untuk pengambilan sampel perusahaan atau mitra industri tempat mahasiswa melaksanakan Praktik Industri, yaitu tiga perusahaan besar, tiga perusahaan menengah, dan tiga perusahaan kecil. teknik pengumpulan data yang digunakan adalah angket, wawancara dan observasi.

Data yang diperoleh melalui kuesioner menggunakan skala semantic differential dengan 5 alternatif jawaban untuk setiap pertanyaan dengan nilai terendah 1 dan nilai tertinggi adalah 5 . Perhitungan skor kriteria menggunakan dasar perhitungan dari Saifuddin Azwar
(2012: 148). Analisis data dalam penelitian ini menggunakan analisis rata-rata dengan menghitung rata-rata setiap komponen evaluasi pada tiap responden. Skor kriteria pada penelitian ini ada lima, yaitu sangat tinggi, tinggi, cukup, rendah, dan sangat rendah. Perhitungan skor yang diperoleh pada masing-masing aspek evaluasi adalah sebagai berikut:

$\mathrm{X}=\underline{\text { Jumlah rata-rata per indikator }}$

Jumlah komponen per indikator

Batasan-batasan kategori berdasarkan rata-rata nilai dapat disusun pada tabel berikut:

Tabel 3.1. Skor Kriteria Penilaian

\begin{tabular}{|c|c|c|}
\hline Rumus & $\begin{array}{c}\text { Rentang } \\
\text { nilai }\end{array}$ & Kategori \\
\hline $\mathrm{X} \leq \mu-1.5 \alpha$ & $\leq 2,1$ & Sangat rendah \\
\hline$\mu-1.5 \alpha<X \leq \mu-0.5 \alpha$ & $>2.1-2.7$ & rendah \\
\hline$\mu-0.5 \alpha<X \leq \mu+0.5 \alpha$ & $>2.7-3.3$ & Cukup \\
\hline$\mu+0.5 \alpha<X \leq \mu+0.5 \alpha$ & $>3.3-3.9$ & Tinggi \\
\hline$\mu+0.5 \alpha \leq X$ & $>3.9$ & Sangat tinggi \\
\hline
\end{tabular}

Skor yang didapat nantinya disusun dalam bentuk narasi dan disusun secara logis serta sistematis untuk memperoleh data yang mudah dipahami dan mempermudah peneliti dalam merangkai maupun menggabungkan keterkaitan antar data. Data hasil dari rata-rata akan didukung oleh data hasil wawancara sehingga mampu memperkuat hasil dari data angket tersebut. 


\section{HASIL PENELITIAN DAN}

\section{PEMBAHASAN}

\section{a. Evaluasi}

Konteks

(Context

\section{Evaluation)}

Evaluasi konteks pada pelaksanaan Praktik Industri di Program Studi

Pendidikan Teknik Mesin UNS yang terdiri dari empat aspek evaluasi disajikan dalam tabel berikut:

Tabel 4.1. Deskripsi Data Komponen Evaluasi Konteks dalam

\begin{tabular}{llccc}
\multicolumn{5}{c}{ Pelaksanaan Program Praktik Industri } \\
\hline No & \multicolumn{1}{c}{ Aspek } & $\begin{array}{c}\text { Rata-rata } \\
\text { per Aspek }\end{array}$ & $\begin{array}{c}\text { Rata-rata } \\
\text { Komponen }\end{array}$ & Kategori \\
\hline 1. & Tujuan Praktik Industri & 3,7 & & \\
2. & Sasaran Praktik Industri & 3,2 & & \\
3. & Relevansi Praktik & 3,7 & 3,5 & Tinggi \\
& Industri & & & \\
4. & Sistem Pengelolaan & 3,3 & & \\
& Praktik Industri & & & \\
\hline
\end{tabular}

Data dari tabel 4.1 ditampilkan dalam histogram berikut:

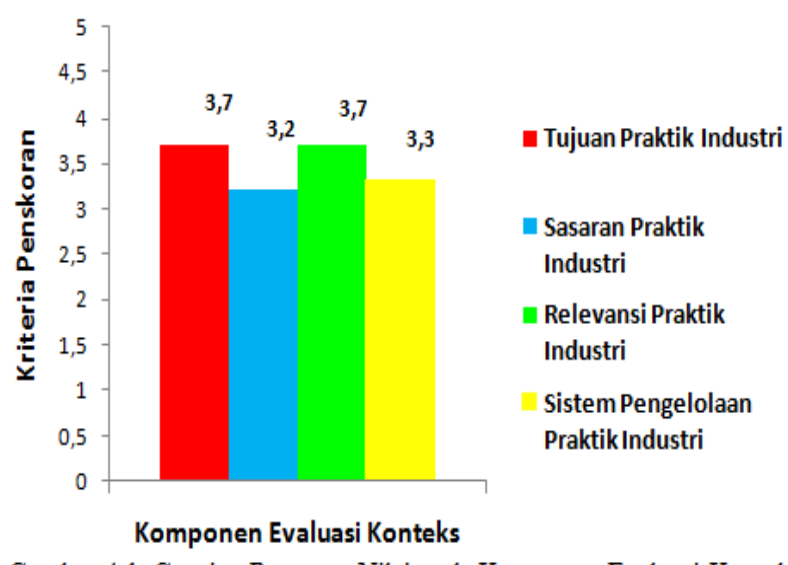

Gambar 4.1. Capaian Rata-rata Nilai pada Komponen Evaluasi Konteks

Berdasarkan penelitian terhadap kualitas evaluasi konteks pada pelaksanaan Program Praktik Industri Program Studi Pendidikan Teknik Mesin UNS pada aspek tujuan program Praktik Industri memperoleh nilai ratarata 3,7. Aspek sasaran program Praktik Industri memperoleh nilai rata-rata 3,2. Aspek relevansi program Praktik
Industri memperoleh nilai rata-rata 3,7. Pada aspek sistem pengelolaan program Praktik Industri memperoleh nilai ratarata 3,3. Rata-rata pada evaluasi konteks adalah 3,5 yang berarti nilai tersebut masuk pada kriteria tinggi. Berdasarkan nilai rata-rata tersebut, konteks dalam pelaksanaan Program Praktik Industri Program Studi Pendidikan Teknik Mesin UNS tergolong tinggi.

\section{b. Evaluasi Masukan (Input Evaluation)}

Evaluasi masukan pada pelaksanaan Praktik Industri di Program Studi Pendidikan Teknik Mesin UNS yang terdiri dari dua aspek evaluasi disajikan dalam tabel berikut:

Tabel 4.2. Deskripsi Data Komponen Evaluasi Masukan dalam Pelaksanaan Program Praktik Industri

\begin{tabular}{lllcc}
\hline No & \multicolumn{1}{c}{ Aspek } & $\begin{array}{r}\text { Rata-rata } \\
\text { per Aspek }\end{array}$ & $\begin{array}{c}\text { Rata-rata } \\
\text { Komponen }\end{array}$ & Kategori \\
\hline 1. & $\begin{array}{l}\text { Penyiapan Pengelolaan } \\
\text { Praktik Industri }\end{array}$ & 2,8 & & \\
2. & $\begin{array}{l}\text { Penyiapan Kompetensi } \\
\text { Mahasiswa }\end{array}$ & 3,5 & 3,1 & Cukup \\
\hline
\end{tabular}

Data dari tabel 4.2 ditampilkan dalam histogram berikut:

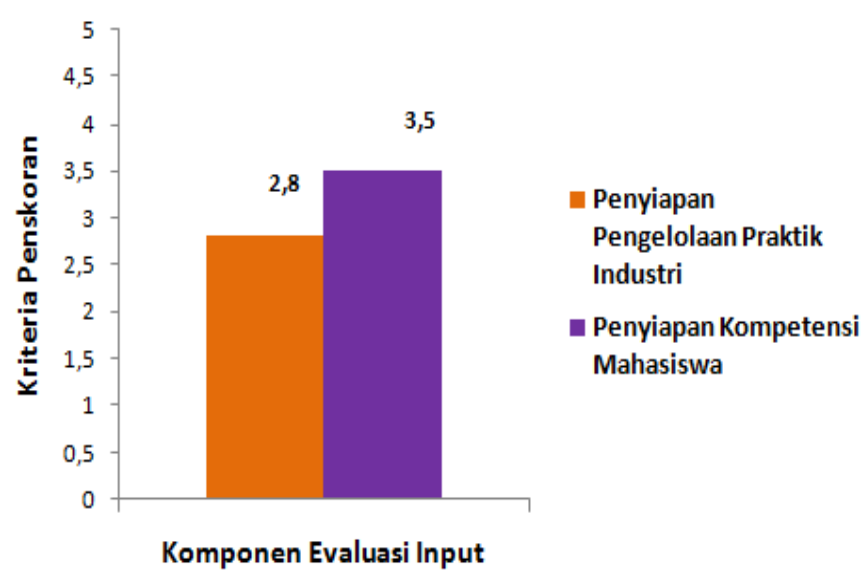

Gambar 4.2. Capaian Rata-rata Nilai pada Komponen Evaluasi Input 
Berdasarkan penelitian terhadap kualitas evaluasi masukan, menunjukkan nilai rata-rata pada komponen evaluasi masukan, yaitu penyiapan pengelolaan dalam rangka pelaksanaan program Praktik Industri memperoleh nilai sebesar 2,8. Nilai rata-rata pada penyiapan kompetensi mahasiswa dalam rangka pelaksanaan program Praktik Industri memperoleh nilai sebesar 3,5. Sehingga nilai ratarata pada komponen evaluasi masukan memperoleh nilai sebesar 3,1. Berdasarkan nilai rata-rata maka pada komponen evaluasi masukan pada pelaksanaan Praktik Industri Program Studi Pendidikan Teknik Mesin UNS tergolong cukup.

\section{c. Evaluasi Proses (Process Evaluation)}

Evaluasi proses pada pelaksanaan Praktik Industri di Program Studi Pendidikan TeknikMesin UNS yang terdiri dari empat aspek evaluasi disajikan dalam tabel berikut:

\begin{tabular}{|c|c|c|c|}
\hline No & Aspek & $\begin{array}{l}\text { Rata-rata } \\
\text { per Aspek }\end{array}$ & $\begin{array}{l}\text { Rata-rata } \\
\text { Komponen }\end{array}$ \\
\hline 1. & $\begin{array}{l}\text { Peran Mahasiswa di } \\
\text { Industri }\end{array}$ & 3,7 & \multirow{4}{*}{3,4} \\
\hline 2. & $\begin{array}{l}\text { Peran Dosen } \\
\text { Pembimbing }\end{array}$ & 2,5 & \\
\hline 3. & $\begin{array}{l}\text { Peran Instruktur di } \\
\text { Industri }\end{array}$ & 3,7 & \\
\hline 4. & $\begin{array}{l}\text { Hambatan Pelaksanaan } \\
\text { Praktik Industri }\end{array}$ & 3,5 & \\
\hline
\end{tabular}

Data dari tabel 4.3 ditampilkan dalam histogram berikut:

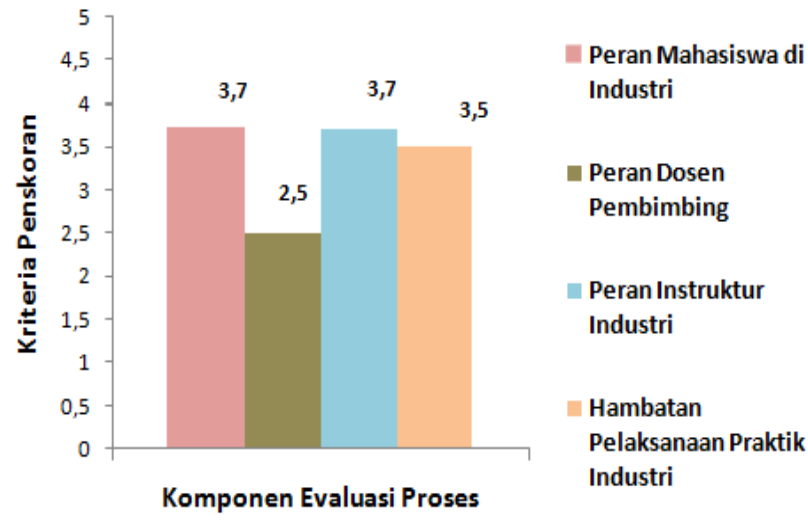

Gambar 4.3. Capaian Rata-rata Nilai pada Komponen Evaluasi Proses

Berdasarkan penelitian terhadap kualitas evaluasi proses, menunjukkan nilai rata-rata pada komponen evaluasi proses, yaitu peran mahasiswa di industri dalam rangka pelaksanaan program Praktik Industri memperoleh nilai sebesar 3,7. Nilai rata-rata pada peran dosen pembimbing dalam rangka pelaksanaan program Praktik Industri memperoleh nilai sebesar 2,5. Nilai rata-rata pada peran instruktur di industri memperoleh nilai sebesar 3,7. dan untuk hambatan dalam pelaksanaan Praktik Industri memperoleh nilai ratarata ssebesar 3,5. Sehingga nilai ratarata pada komponen evaluasi proses memperoleh nilai sebesar 3,4. Berdasarkan nilai rata-rata maka pada komponen evaluasi proses pada pelaksanaan Praktik Industri Program Studi Pendidikan Teknik Mesin UNS tergolong tinggi.

\section{d. Evaluasi Produk (Product Evaluation)}

Evaluasi produk pada pelaksanaan Praktik Industri di Program Studi Pendidikan Teknik Mesin UNS yang 
terdiri dari lima aspek evaluasi disajikan dalam tabel berikut:

Tabel 4.4. Deskripsi Data Komponen Evaluasi Produk dalam Pelaksanaan Program Praktik Industri

\begin{tabular}{lllll}
\hline No & \multicolumn{1}{c}{ Aspek } & $\begin{array}{l}\text { Rata-rata } \\
\text { per Aspek }\end{array}$ & $\begin{array}{c}\text { Rata-rata } \\
\text { Komponen }\end{array}$ & Kategori \\
\hline 1. & $\begin{array}{l}\text { Pengembangan } \\
\text { personalitas mahasiswa }\end{array}$ & 3,7 & & \\
2. & $\begin{array}{l}\text { Pengembangan } \\
\text { keterampilan mahasiswa }\end{array}$ & 3,7 & & \\
3. & $\begin{array}{l}\text { Kesiapan keja } \\
\text { mahasiswa }\end{array}$ & 3,6 & 3,7 & Tinggi \\
4. $\begin{array}{l}\text { Pengalaman inovatif } \\
\text { mahasiswa }\end{array}$ & 3,7 & & \\
5. Kepuasan mahasiswa & 3,6 & & \\
\hline
\end{tabular}

Data dari tabel 4.4 ditampilkan dalam histogram berikut:

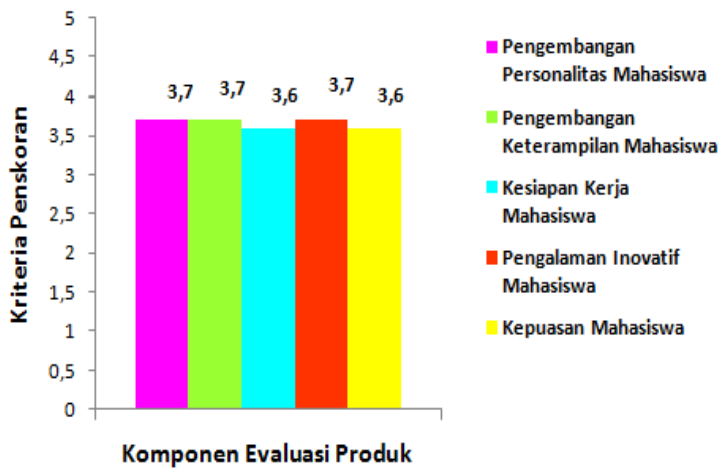

Gambar 4.4. Capaian Rata-rata Nilai pada Komponen Evaluasi Produk

Berdasarkan penelitian terhadap kualitas evaluasi produk, menunjukkan nilai rata-rata pada komponen evaluasi produk yaitu pengembangan personalitas memperoleh nilai sebesar 3,7. Nilai rata-rata pada pengembangan keterampilan memperoleh nilai sebesar 3,7. Nilai rata-rata pada kesiapan kerja mahasiswa memperoleh nilai sebesar 3,6. Untuk pengalaman inovatif mahasiswa memperoleh nilai rata-rata sebesar 3,7. Dan untuk tingkat kepuasan mahasiswa setelah melaksanakan Praktik Industri memperoleh nilai ratarata sebesar 3,6. Sehingga nilai rata-rata pada komponen evaluasi produk memperoleh nilai sebesar 3,7. Berdasarkan nilai rata-rata maka pada komponen evaluasi produk pada pelaksanaan Praktik Industri Program Studi Pendidikan Teknik Mesin UNS tergolong tinggi.

Berdasarkan keempat komponen evaluasi tersebut, kualitas pelaksanaan program Praktik Industri di Program Studi Pendidikan Teknik Mesin UNS disajikan pada tabel berikut:

Tabel 4.5. Kualitas Pelaksanaan Program Praktik Industri di Program Studi Pendidikan Teknik Mesin UNS

\begin{tabular}{lllcc}
\hline No & \multicolumn{1}{c}{ Aspek } & $\begin{array}{c}\text { Rata-rata } \\
\text { per Aspek }\end{array}$ & $\begin{array}{c}\text { Rata-rata } \\
\text { Komponen }\end{array}$ & Kategori \\
\hline 1. & Evaluasi Konteks & 3,4 & & \\
2. & Evaluasi Masukan & 3,1 & 3,4 & Tinggi \\
3. & Evaluasi Proses & 3,3 & & \\
4. & Evaluasi Produk & 3,7 & & \\
\hline
\end{tabular}

Data dari tabel 4.5 ditampilkan dalam histogram berikut:

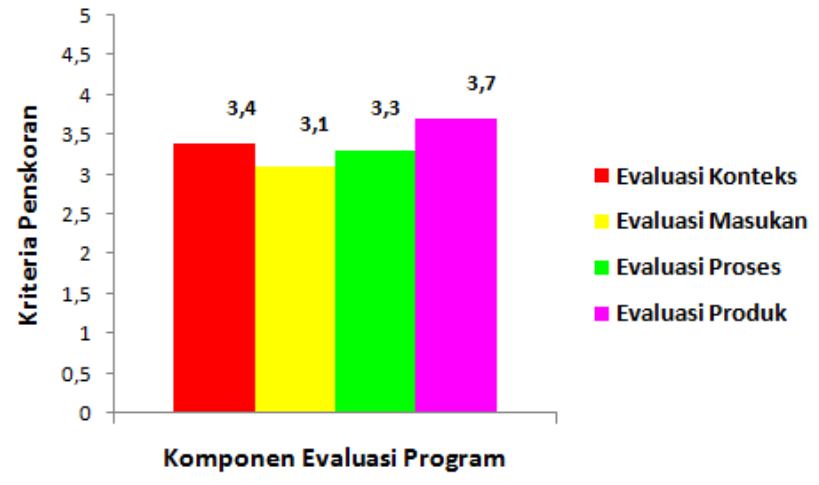

Gambar 4.5. Histogram Komponen Evaluasi Program

Pada hasil penelitian terhadap pelaksanaan Praktik Industri, evaluasi konteks memperoleh nilai rata-rata sebesar 3,4. Evaluasi masukan memperoleh rata-rata nilai sebesar 3,1. Evaluasi proses memperoleh nilai ratarata sebesar 3,3. Evaluasi produk memperoleh nilai rata-rata sebesar 3,7. Dengan demikian nilai total 
pelaksanaan Praktik Industri di Program Studi Pendidikan Teknik Mesin UNS adalah 3,4. Berdasarkan kriteria penilaian, nilai tersebut tergolong tinggi. Hal ini menunjukkan bahwa kualitas pelaksanaan Program Praktik Industri di Program Studi Pendidikan Teknik Mesin UNS tergolong tinggi.

\section{SIMPULAN DAN SARAN}

\section{Simpulan}

Berdasarkan hasil penelitian dan pembahasan tentang pelaksanaan Program Praktik Industri di Program Studi Pendidikan Teknik Mesin Universitas Sebelas Maret Surakarta, maka dapat ditarik kesimpulan sebagai berikut:

\section{Evaluasi Konteks (Context}

\section{Evaluation)}

Evaluasi terhadap konteks Program Praktik Industri di Program Studi Pendidikan Teknik Mesin Universitas Sebelas Maret Surakarta menunjukkan hasil yang efektif karena pada aspek tersebut tergolong dalam kategori tinggi dan telah terpenuhinya kriteria konteks yang telah ditentukan, yaitu pada aspek tujuan praktik industri, sasaran praktik industri, sistem pengelolaan praktik industri, dan relevansi praktik industri.

a. Tujuan praktik industri yang telah ditetapkan oleh Program Studi Pendidikan Teknik Mesin
Universitas Sebelas Maret Surakarta tergolong dalam kategori tinggi.

b. Sasaran praktik industri yang telah ditetapkan Program Studi Pendidikan Teknik Mesin Universitas Sebelas Maret Surakarta tergolong kategori cukup.

c. Sistem pengelolaan praktik industri di Program Studi Pendidikan Teknik Mesin Universitas Sebelas Maret Surakarta tergolong dalam kategori tinggi.

d. Relevansi praktik industri yang tercapai di Program Studi Pendidikan Teknik Mesin Universitas Sebelas Maret Surakarta tergolong kategori cukup.

Dengan tingginya kualitas konteks pada pelaksanaan praktik industri makadapat dijadikan sebagai penunjang awal dalam pelaksanaan Program Praktik Industri di Program Studi Pendidikan Teknik Mesin Universitas Sebelas Maret Surakarta.

\section{Evaluasi Masukan (Input Evaluation)}

Evaluasi terhadap input Program Praktik Industri di Program Studi Pendidikan Teknik Mesin Universitas Sebelas Maret Surakarta menunjukkan hasil yang efektif karena pada aspek tersebut tergolong dalam kategori cukup dan telah terpenuhinya kriteria input yang telah ditentukan, yaitu pada aspek penyiapan pengelolaan program praktik 
industri dan penyiapan kompetensi mahasiswa.

a. Penyiapan pengelolaan program dalam rangka pelaksanaan Program Praktik Industri di Program Studi Pendidikan Teknik Mesin Universitas Sebelas Maret Surakarta tergolong dalam kategori cukup dalam penyiapannya.

b. Penyiapan kompetensi mahasiswa sebagai bekal dalam rangka pelaksanaan Program Praktik Industri di Program Studi Pendidikan Teknik Mesin Universitas Sebelas Maret Surakarta tergolong dalam kategori yang tinggi sehingga siap untuk melaksanakan Program Praktik Industri.

Dengan berlandaskan aspek konteks yang tinggi maka didapatkan aspek input yang sudah baik pula dalam pelaksanaan Program Praktik Industri di Program Studi Pendidikan Teknik Mesin Universitas Sebelas Maret Surakarta.

\section{Evaluasi Proses (Process Evaluation)}

Evaluasi terhadap proses dalam pelaksanaan Program Praktik Industri di Program Studi Pendidikan Teknik Mesin Universitas Sebelas Maret Surakarta menunjukkan hasil yang efektif karena pada aspek tersebut tergolong dalam kategori tinggi dan telah terpenuhinya kriteria proses yang telah ditentukan, yaitu peran mahasiswa, peran dosen pembimbing, peran instruktur industri, dan hambatan pelaksanaan praktik industri.

a. Peran mahasiswa dalam pelaksanaan Program Praktik Industri di Program Studi Pendidikan Teknik Mesin Universitas Sebelas Maret Surakarta tergolong dalam kategori yang tinggi.

b. Peran dosen pembimbing dalam pelaksanaan Program Praktik Industri di Program Studi Pendidikan Teknik Mesin Universitas Sebelas Maret Surakarta tergolong masih rendah rendah dan perlu adanya peningkatan pada kinerja dosen pembimbing.

c. Peran instruktur di industri dalam pelaksanaan Program Praktik Industri di Program Studi Pendidikan Teknik Mesin Universitas Sebelas Maret Surakarta tergolong tinggi dan sudah baik.

d. Hambatan pelaksanaan Program Praktik Industri di Program Studi Pendidikan Teknik Mesin Universitas Sebelas Maret Surakarta tergolong dalam kategori tinggi yang berarti hambatan pada pelaksanaan praktik industri relatif kecil. Faktor penghambat dalam pelaksanaan Program Praktik Industri antara lain: (1) adaptasi peserta praktik industri dengan lingkungan industri 
rendahnya penggantian posisi pekerjaan (rolling job) mahasiswa di industri yang menyebabkan mahasiswa jenuh dan kurang mendapatkan pengalaman ilmu baru dan kompetensi yang lebih (3) keterbatasan kemampuan peserta praktik industri dalam hal penggunaan sarana dan prasarana di industri (4) keterbatasan bekal pengetahuan peserta praktik industri (5) kurangnya relevansi ilmu dikampus dengan pekerjaan di industri (6) kurangnya kinerja dosen pembimbing praktik industri (7) kurangnya kinerja admin sistem pengelolaan praktik industri (8) Tahap pengajuan dalam pelaksanaan praktik indutri di industri yang terkadang harus menunggu lama dan hasilnya ditolak (9) Komunikasi yang dirasa kurang antara dosen pembimbing dan mahasiswa praktikan pada saat pelaksanaan praktik industri(10) seminar praktik industri mahasiswa yang cenderung telat (11) Belum adanya partner industri yang tetap (12) kurangnya waktu dalam pelaksanaan praktik industri di industri (13) belum adanya buku pedoman Praktik Industri dari program studi.

\section{Evaluasi Produk (Product Evaluation)}

Evaluasi terhadap produk pada pelaksanaan Program Praktik Industri di Program Studi Pendidikan Teknik Mesin Universitas Sebelas Maret Surakarta menunjukkan hasil yang tergolong tinggi karena mampu meningkatkan kemampuan mahasiswa praktikan dan bermanfaat bagi pihak program studi.

a. Pengembangan personalitas mahasiswa tergolong tinggi karena terbukti dengan adanya program praktik industri kemampuan mahasiswa praktikan dalam hal softskill meningkat.

b. Pengembangan keterampilan mahasiswa tergolong tinggi karena terbukti dengan adanya program praktik industri kemampuan mahasiswa praktikan dalam hal hardskill meningkat.

c. Kesiapan kerja mahasiswa tergolong tinggi karena terbukti dengan adanya program praktik industri mahasiswa merasa lebih siap untuk bekerja di industri.

d. Pengalaman inovatif mahasiswa tergolong tinggi karena terbukti dengan adanya program praktik industri mahasiswa mampu membantu memecahkan permasalahan terkait tugas-tugas pada saat pelaksanaan praktik industri. 
e. Kepuasan mahasiswa tergolong tinggi karena terbukti dengan adanya program praktik industri sudah mendapat gambaran pada saat bekerja di industri.

\section{Saran}

Berdasarkan hasil penelitian dan analisis data hasil penelitian maka peneliti dapat memberikan saran sebagai berikut:

\section{Kepala Program Studi}

Berdasarkan hasil penelitian maka peniliti dapat memberikan saran kepada pihak program studi sebagai berikut:

a. Program studi hendaknya melakukan evaluasi terhadap kebutuhan industri untuk meningkatkan kompetensi mahasiswa sehingga lebih siap dalam pelaksaan Program Praktik Industri.

b. Melakukan perbaikan pada sistem pengelolaan dan administrasi Program Praktik Industri.

c. Meningkatkan kinerja dosen dalam hal pembimbingan terhadap mahasiswa pelaksana Program Praktik Industri.

d. Meningkatkan hubungan kerjasama dengan industri dalam hal penempatan mahasiswa pada saat pelaksanaan Program Praktik Industri. e. Meningkatkan alokasi waktu pelaksanaan Program Praktik Industri.

\section{Industri}

Berdasarkan hasil penelitian, maka peneliti dapat memberikan saran kepada pihak industri sebagai berikut:

a. Mitra industri dapat meningkatkan keterbukaan dalam hal penerimaan mahasiswa pelaksana Program Praktik Industri.

b. Mitra industri mampu meningkatkan kontribusi mahasiswa pelaksana Program Praktik Industri.

\section{Mahasiswa}

Berdasarkan hasil penelitian maka peneliti dapat memberikan saran kepada pihak mahasiswa sebagai berikut:

a. Mahasiswa hendaknya berkomitmen tinggi dalam pelaksanaan Program Praktik Industri.

b. Mahasiswa diharapakan berkontribusi penuh dalam pelaksanaan Program Praktik Industri.

c. Mahasiswa diharapkan mampu menjaga hubungan kerjasama antara pihak Universitas dengan pihak industri.

d. Mahasiswa diharapkan menjaga nama baik Universitas Sebelas Maret. 
e. Mahasiswa diharapkan mampu menyelesaikan kewajiban penyelesaian laporan Praktik Industri tepat waktu.

\section{Peneliti Selanjutnya}

Berdasarkan hasil penelitian maka peneliti dapat memberikan saran kepada peneliti selanjutnya diharapkan penelitian terhadap pelaksanaan Program Praktik Industri menggunakan metode yang lebih mendalam dan lebih baik.

\section{DAFTAR PUSTAKA}

Arikunto, Suharsimi \& Jabar, Cepi S.A. (2009). Evaluasi program pendidikan: Pedoman Teoritis Praktis bagi Mahasiswa dan Praktisi Pendidikan. Jakarta: Bumi Aksara.

Arisma, Deby. (2013). Evaluasi Program Pendidikan Sistem Ganda Di Sekolah Menengah Kejuruan (Studi Kasus Di SMK Bhineka Karya Surakarta Jurusan Otomotif). Skripsi Tidak Dipublikasikan. Universitas Sebelas Maret, Surakarta.

Azwar, Saifuddin. (2012). Sikap Manusia Teori dan Pengukurannya. Yogyakarta: Pustaka Pelajar.

Badan Pusat Statistik. (2015). Kondisi Ketenagakerjaan Februari 2015. Diperoleh 19 Januari 2016 dari http://www.bps.go.id/brsfile/ naker.pdf.

Tim Skripsi Uns. (2016). Pedoman Penulisan Skripsi 2016. UNS PRESS: Universitas Sebelas Maret, Surakarta.
Widoyoko, Eko Putro. (2014). Evaluasi Program Pembelajaran Panduan Praktis Bagi Pendidik dan Calon Pendidik. Yogyakarta: Pustaka Pelajar. 